\title{
L'herència del debat literari sobre la condició femenina en l'obra dramàtica de Francesc Palanca i Roca
}

\section{The Inheritance of the Literary Debate on the Female Condition in Francesc Palanca i Roca's Dramatic Work}

\author{
Hilari Garcia GÁzQuez \\ hilarigarcia@hotmail.com \\ Universitat de València
}

\begin{abstract}
Resum: Els estudiosos del teatre del segle XIX consideren que els gèneres escènics vuitcentistes, en especial el sainet, són una font de documentació de la societat d'aquells anys. En conseqüència, a través d'una part important de la producció dramàtica de Francesc Palanca i Roca (1834-1897) podem resseguir els hàbits, els costums i les tradicions dels valencians d'aquell període, fins i tot la disputa o el debat al voltant de les dones que inundava els ambients literaris i acadèmics europeus des de l'edat mitjana. En aquest sentit, observarem com les obres per a escena de Palanca i Roca recullen l'herència dels tòpics misògins i dels arguments en defensa de la condició femenina, una herència que procedeix tant de la literatura culta com de la popular. En definitiva, la detecció i identificació d'aquests elements serà l'objectiu del present treball.
\end{abstract}

Paraules clau: misogínia, teatre, sainet

Abstract: 19th century researchers consider that 18th century drama genres, especially the «sainet» (a comic sketch), are a source of documentation on those years society. Consequently, we can follow the habits, uses and traditions of the Valencian people of that period through an important part of the drama production by Francesc Palanca i Roca (1834-1897), even the dispute or debate on women that used to flood the European literary and academic circles of the medieval age. In this respect, we will see how the drama plays by Palanca i Roca gather the heritage of misogynous topics and the arguments on women's condition defence, a heritage coming from the cultivated literature as well as from the popular one. All in all, the detection and identification of these elements will be the objective of the present work.

Keywords: misogyny, theatre, sainet 
Hilari Garcia Gázquez. L’herència del debat literari sobre la condició femenina en l'obra dramàtica de Francesc Palanca i Roca

\section{Preàmbul. El teatre del segle XIX i els tòpics d'una disputa secular}

El segle XIX és el període d'eclosió del gènere teatral, tant pel que fa al volum de producció, com al nombre d'espectadors o a la quantitat de nous espais escènics creats. És cert que des del punt de vista de la qualitat de la literatura dramàtica, no hi havia massa originalitat en les obres, i principalment es continuava la pràctica de gèneres considerats menors procedents dels segles anteriors. Gèneres que tenien com a objectiu el passatemps amb diversió i comicitat, a fi de satisfer un públic variat i divers amb l'única voluntat d'entretenir. Aquesta inèrcia també l'heretaren els models escènics nous, com la sarsuela, el sainet o el melodrama moderns, la qual cosa va provocar que les representacions teatrals foren un autèntic fenomen de masses durant el huit-cents (Garcia 2015).

Per als estudiosos de la societat del segle XIX, el teatre d'aquells anys és una font impagable d’informació, ja que a través de les seues línies se'ns permet conéixer les gents, els costums, els gustos, el caràcter i les tradicions d'un país i d'una cultura. En paraules de Xavier Fàbregas (1979: 5):

Si desapareguessin les fonts de documentació d'aquest segle, però els sainets sortissin miraculosament salvats de la pèrdua, podríem reconstruir la fisonomia de la nostra societat, en podríem seguir l'evolució amb una fidelitat absoluta: la relació entre les diferents classes socials, el pas del menestral acomodat a burgès, de terratinent a rentista, de petit artesà a obrer industrial, la transformació urbana.

No obstant això, és possible que en alguns casos particulars aquest suposat reflex de la realitat del moment siga el resultat d'una visió esbiaixada, com suggereix Baldó (1995) respecte de la producció d'Eduard Escalante. En aquest sentit, és interessant recordar que Gabriel Sansano (2014: 326) especifica:

\footnotetext{
L'obra d'Eduard Escalante sempre provoca la discussió de si fou un fotògraf realista de la societat valenciana de l'època (el tòpic més habitual des del seu temps ençà), o si, com apunten alguns historiadors (per exemple, Marc Baldó), el dramaturg reflecteix una societat inexistent, allunyada de les condicions de vida de les classes humils i de la conflictivitat social del darrer terç del segle XIX. Avui dia sembla evident que Escalante reflectí els seus veïns i certs ambients, però sempre des d'una òptica idealitzada, des d'un punt de vista bonhomiós, lleument moralitzador i sense decantar-se per cap actitud de crítica social que poguera resultar estrident en la pau de la societat burgesa que representaven alguns dels seus amics.
}

Siga com siga, les captures nítides o distorsionades de la societat huitcentista són un tret ben significatiu d'aquest teatre. Un teatre que, tot i haver rebut els qualificatius de simple, caricaturesc, maniqueu o estereotipat i malgrat els prejudicis amb què conviu, posseeix una càrrega cultural inqüestionable per al sociòleg, l'historiador i, per què no, també per al filòleg. No en va, representà la manifestació cultural més important a la qual podia assistir un públic de procedència heterogènia, 
que demanava un factor de divertiment i de socialització. Aquesta demanda, que creixia amb el temps, tingué una resposta per part dels empresaris i els dramaturgs teatrals amb la consegüent creació i construcció de sales i teatres arreu del país i amb la producció ingent de peces dramàtiques (Sansano 1997).

Els estudis, cada vegada més nombrosos, d'aquestes obres i de la seua recepció mostren la continuïtat i la recreació de tòpics i estereotips de la tradició literària culta i popular. En efecte, la major part d'aquestes peces arrepleguen tots els llocs comuns de les manifestacions escèniques i de les pràctiques literàries dels segles anteriors. Per tant, si es volia fer plorar, els melodrames utilitzaven els elements reiterats i freqüents per a aconseguir la llàgrima fàcil. En canvi, per a aconseguir la comicitat, com és el cas de la major part de peces del teatre valencià del XIX, es recorria a una sèrie d'elements burlescos, eròtics, satírics i fins i tot escatològics. Entre aquests elements per a la burla i la sàtira es trobava la misogínia i la crítica sarcàstica a la condició femenina.

En concret, en l'obra teatral del lletraferit valencià Francesc Palanca i Roca (Alzira, 1834 València, 1897), un dramaturg encara per descobrir entre els valencians actuals però amb una fama extraordinària durant el seu temps, trobem reflectits aquests tòpics misògins heretats de la tradició literària. Aquesta pràctica, que procedeix sobretot dels col loquiers del segle XVIII, beu al seu torn del llegat medieval que té el seu punt culminant a casa nostra amb l'Espill de Jaume Roig i que troba continuació en la nostra praxi literària, tant culta com popular, dels segles XVI i XVII. Comptat i debatut, la plasenteria misògina és un motiu recurrent en la literatura popular del segle XVIII, la coneguda com la literatura de canya $i$ cordell, que arreplega els tòpics misògins medievals amb la presentació dels personatges femenins ridiculitzats pels seus vicis i capritxos.

$\mathrm{Al}$ costat de la crítica i la sàtira misògina en la producció de Palanca i Roca també trobem el discurs de la, diguem-ne, filogínia, igualment present en la tradició literària del nostre entorn des d'antany i sorgida com a reacció a la burla i l'escarni cap a les dones en els textos literaris. De fet, el debat sobre la condició femenina s'havia suscitat en la literatura en llengua vulgar des del segle XIII (Cantavella 1992b). A casa nostra, el debat literari pro i antifeminista, que també es coneix amb l'expressió francesa querelle des femmes, viurà el moment més àlgid al segle XV. Com afirma Antònia Carré (2007: 43-44) referint-se a aquell període:

\footnotetext{
Van sorgir autors i obres alineats en les files dels antifeministes i d'altres en les dels profeministes, que anaven repetint una sèrie de tòpics que van fer fortuna al llarg de tota l'edat mitjana. El fet de prendre part en el debat no volia dir que fossin més o menys misògins que els seus companys de generació, sinó que significava que participaven en un debat d’èxit assegurat, ja que de vegades trobem els mateixos autors defensant les dues postures antagòniques.
} 
Aquests tòpics que s'utilitzaren a bastament en aquesta controvèrsia al voltant de la condició femenina van perviure en les pràctiques literàries dels segles posteriors fins a arribar al segle XIX. En conseqüència, es pot traçar una línia contínua de l'ús dels elements comuns derivats del debat entre misògins i filògins, que travessa la nostra literatura, tant culta com popular, i que podem resseguir fins als nostres dies. Per a tal fi, i focalitzant-nos en l'obra dramàtica de Palanca i Roca, en primer lloc rastrejarem els ingredients que s'hi fan servir per a dur a terme la burla misògina i, a continuació, les raons esmerçades per a la defensa de la condició femenina. Finalment, unes conclusions tancaran el breu però intens trajecte per aquesta disputa literària secular.

\section{La sàtira misògina en la producció de Palanca i Roca}

En les obres de teatre del segle XIX, no només en els sainets sinó també en aquelles que tenen un caràcter més ambiciós, hi trobarem bona part dels elements misògins que deriven de la visió androcèntrica de la societat, segons la qual l'home és el ser més perfecte de la creació mentre la dona és un ser secundari i accessori. Aquesta idea ve de lluny: els grecs i els romans ja la reflectien d'alguna manera en els seus mites i les religions monoteistes derivades de les creences dels pobles semítics tenen des de l'origen aquesta concepció. Un dels nostres clàssics, Bernat Metge, ho deixa ben clar al Llibre III de Lo somni, a través de Tirèsies:

Fembra és animal imperfet, de passions diverses, desplasents e abominables passionat, no amant altra cosa sinó son propi cos e delits; e si los hòmens la miraven així com deurien, pus haguessen fet ço que a generació humana pertany, així li fugirien com a la mort. No és animal en lo món menys net que fembres (Metge, 1999: 126-127).

D’altra banda, als segles XVIII i XIX aquesta crítica misògina ancestral, a més, anava lligada a la crítica del matrimoni, ja que les desgràcies conjugals s'atribuïen a les esposes. Això s'explica perquè el model de matrimoni estava basat en la desigualtat tradicional entre els sexes, és a dir, l'home era l'autoritat i la dona hi havia d'estar sotmesa. Per tant, la burla misògina servia per a criticar la dona que no feia cas a l'home a fi de contraposar-la a la dona plena de virtuts, que havia de ser dòcil i servicial (Gomis 2008).

Si reduïm la distància focal i ens centrem en la producció teatral de Palanca i Roca, podem detectar diversos moments d'aquesta vinculació entre crítica misògina i crítica al matrimoni. Per exemple, en la sarsuela Un parent del atre món, estrenada en 1872, amb música de Josep Jordà Valor, el personatge d'Andreu protesta: ${ }^{1}$

1 D'acord amb la pràctica habitual en l'edició filològica de textos, hem transcrit fidelment el testimoni del text: s'ha respectat de manera escrupolosa la grafia i s'ha regularitzat només la disposició dels versos, la puntuació, l'ús de majúscules i minúscules, l'accentuació i la separació de paraules, utilitzant el guionet i l'apòstrof segons les normes actuals i el punt volat en el cas de les aglutinacions no previstes per la normativa. També en els títols de les obres. Així mateix, fem servir l'accent amb caràcter diacrític sobre la à que representa el verb haver, per tal de diferenciar-lo de la preposició $a$. 


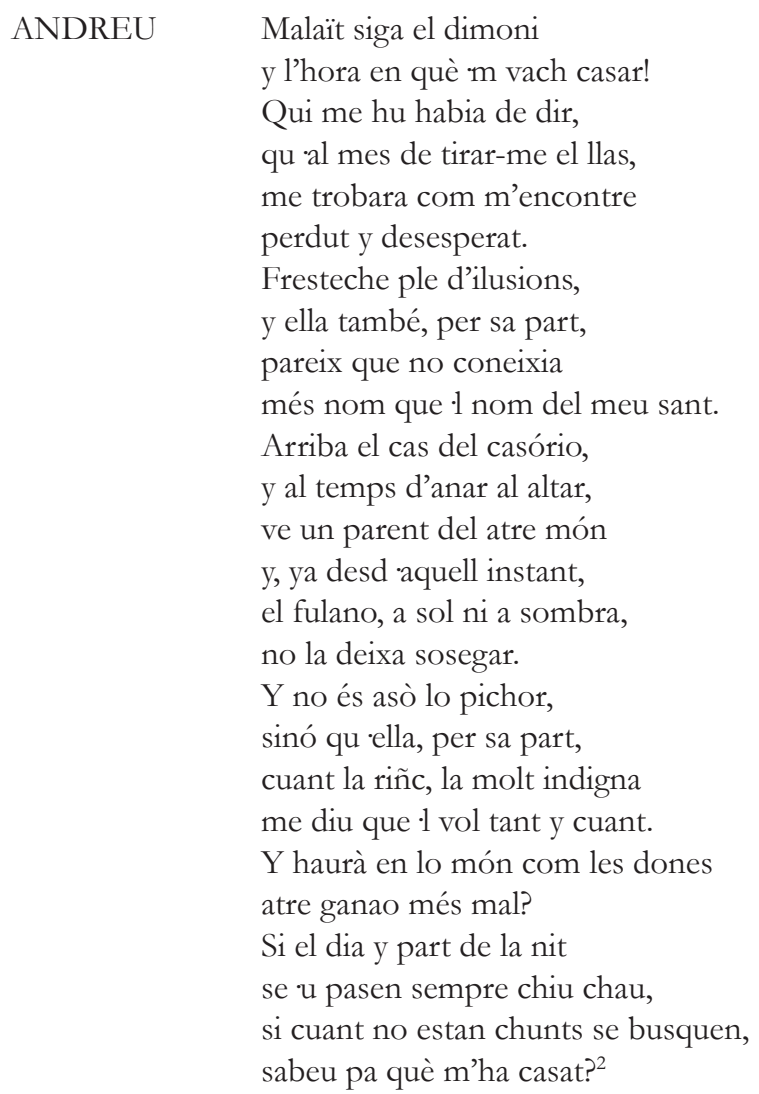

De fet, aquesta crítica al matrimoni s'observa en moltes obres de Palanca, ja que aquesta institució no es percep com una unió entre dues persones que s'estimen, sinó com un instrument per a prosperar socialment o per a conservar les propietats familiars. Això és, hi ha també la crítica als matrimonis concertats per diversos interessos, tan habituals en aquells anys, i que podem trobar en les obres Tres roses en un pomell (1870), Dos gotes d'aigua (1871), Un niu d'enredros (1873), Els dos anells (1874), La gata moixa (1874), Decrets de la Providènsia (1878), Ortigues y roselles (1884), El capital y el treball (1885) o Dos secrets en dos femelles (1925). Al capdavall, la crítica al matrimoni es pot entendre com un equivalent a la crítica misògina que ens condueix sempre a un fet comú: la inferioritat de les dones en unes societats dominades pels homes.

Quant als tòpics misògins en concret, val a dir que les referències contínues a la creació d'Eva i a la causa del pecat original, un dels motius més recurrents de la literatura misògina, els trobem de manera reiterada en les peces de Palanca i Roca. Així, partim del fet que Eva és un ser creat mitjançant una costella d'Adam, amb l'objectiu de fer-li companyia i, a més, Eva és la culpable de la condemna del pecat original, ja que es va deixar seduir pel dimoni disfressat de serp i va arrossegar Adam i la humanitat sencera al patiment. Aquests elements, Eva, la serp o la costella, són freqüents per exemple a l'obra Llàgrimes de una femella, de 1859, on la protagonista femenina proclama:

2 Un parent del atre món (sarsuela bilingüe en dos actes, orchinal y en vers), València, Impremta de Joan Guix, 1872, pp. 35-36 
Hilari Garcia Gázquez. L'herència del debat literari sobre la condició femenina en l'obra dramàtica de Francesc Palanca i Roca

MARIA Això és un vol c à pegat, vol c apenes tira u pam, y en cuant yo toque el reclam caurà dins del enfilat. Si ell en atre camp se seba li estarà la festa cara. Ay! No sap ell encara cuant pot una filla d'Eva. ${ }^{3}$

I continua:

MARIA Compendre volguera yo si, al traure-li la costella, trovàreu, Siñor, en ella gran diferènsia en la casta. Digau-me si és d'atra pasta que la que té esta femella! $!^{4}$

Fixem-nos també en el que diu la protagonista femenina de La millor raó, el trabuc, igualment estrenada en 1859:

$\begin{array}{ll}\text { PASCUALA } & \text { La dona sense un costat } \\ & \text { és un abret sense flor, } \\ & \text { és tórtola que } 1 \text { seu plor } \\ & \text { desgarra en la soletat; } \\ & \text { és un manantial secat, } \\ & \text { és un camp sense profit; } \\ & \text { que si no 's respon al crit } \\ & \text { que pega el cor en lo intern } \\ \text { pases la vida en l'infern. } & \\ \text { Cuan bo deu ser un marit }{ }^{5}\end{array}$

Per la seua banda, en l'obra Lo que sembres, culliràs! de 1871, Rafael tampoc no es queda curt pronunciant aquestes paraules:

RAFAEL Eixa eres tu, sí señores, convé molt que tot se sàpia: la víbora és venenosa y, a hon se la troba, s'aplasta. ${ }^{6}$

3 Llàgrimes de una femella (choguet en un acte y en vers), València, Impremta de la Regeneració Tipogràfica, 1859, p. 17.

4 Op. cit., p. 18.

5 La millor raó, el trabuc (pesa en un acte y en vers), València, Impremta de D. Julià Mariana, 1859, p. 14.

6 Lo que sembres, culliràs! (drama bilingüe de costums valensianes en tres actes y en vers), València, Joan Mariana i Sanz, editor, 1871, p. 29

SCRIPTA, Revista internacional de literatura i cultura medieval i moderna, núm. 16 / desembre 2020 / pp. 383-399 ISSN: 2340-4841 · doi:10.7203/SCRIPTA.16.19236 
Això sense oblidar la frase lapidària «(...) les femelles / tenen empelt de culebra!», que es pot llegir en l'obra pòstuma de Palanca i Roca, Dos secrets en dos femelles, estrenada en 1925, proferida pel personatge de Mariano. ${ }^{7}$

Tanmateix, el que més crida l'atenció dels fragments anteriors és que en els primers són les dones mateixes que, inserides en un entorn patriarcal, assumeixen la seua condició de ser complementari a l'home. Fins i tot assumeixen la maldat i l'astúcia que li assignen els homes, com afirma Maria en Llàgrimes d'una femella, que està preparant una trampa al seu marit Pau, gelós i possessiu, fent-li creure que sedueix un soldat que la pretén:

MARIA Lo que no sap una dona, pare, no ho sap el dimoni. Ya tinc les enses, les vares, els paranys, el enfilat.... en fi, tot està arreglat. ${ }^{8}$

No obstant això, de la mateixa manera que en ocasions trobem els tòpics del discurs misogin en boca de les dones, també tindrem exemples de crítica andrògina expressats per homes. Amb tot, cal copsar aquesta crítica amb precaució, perquè darrere d'una pretesa ridiculització dels homes el que hi ha és, de nou, la satirització de la condició femenina. Una mostra d'aquest exercici la veiem en l'obra Tres roses en un pomell, estrenada en 1870, on Batiste, remetent de nou al pecat original, descriu la naturalesa submisa i quasi masoquista dels homes davant del poder malvat de les dones, que fan el que volen amb ells:

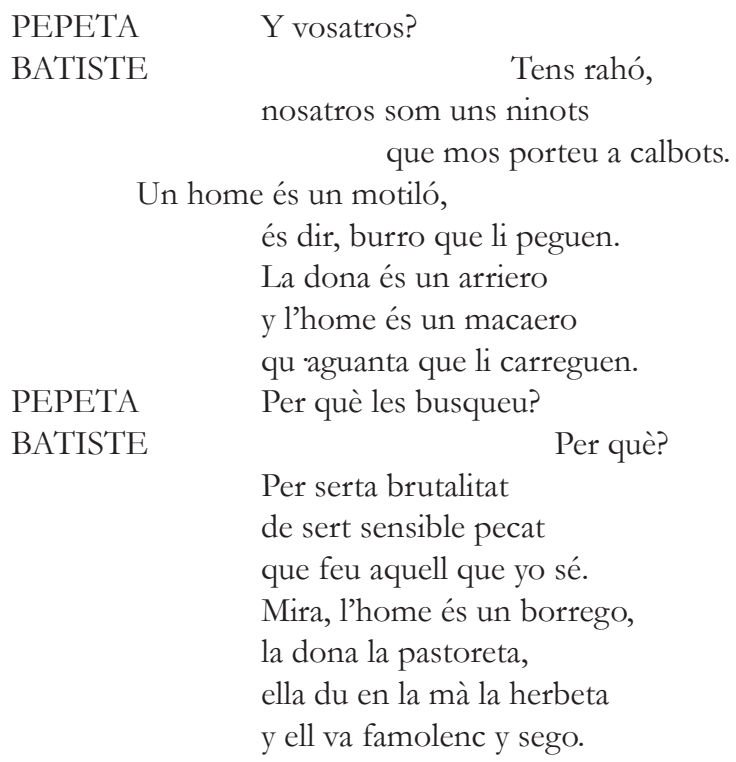

7 Dos secrets en dos femelles (choguet còmic en un acte y en vers), València, Impremta editorial «Artes y Letras», 1925, p. 7. 8 Op. cit., p. 18. 


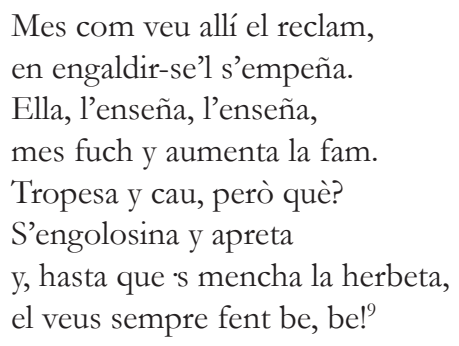

Entre els tòpics misògins que més recorregut han tingut en la cultura occidental destaca el de la famosa ària de Rigoletto de Verdi «La donna è mobile.» Aquesta consideració de la dona com una persona voluble, capritxosa, amb canvis de caràcter i d'opinió i amb qui no es pot confiar, la trobem reflectida en el següent extracte de Lo que sembres, culliràs!

\begin{tabular}{|c|c|}
\hline RAFAEL & $\begin{array}{l}\text { Això vol dir qu eixa cara } \\
\text { muda tantes carasetes } \\
\text { com dies té la setmana. } \\
\text { Vol dir també que } 1 \text { que 's fie } \\
\text { d'eixa serp c atrau i mata } \\
\text { s'omplirà el cor de veneno, } \\
\text { cremant-li entraña en entraña. } \\
\text { Y cuant vecha que no queda } \\
\text { res qu emponsoñar, cuant hacha } \\
\text { romput del teixit del cor } \\
\text { hasta la fibra més alta, } \\
\text { del qu és màrtir l'agonia } \\
\text { mirarà en risa sarcàstica. }{ }^{10}\end{array}$ \\
\hline
\end{tabular}

Una imatge que es repeteix en Tres roses en un pomell, amb l'afirmació de Bernat que ara reproduïm:

BERNAT (...) y el caràcter de Pepeta

Que, sense tindre res mal,

És veleidós, y sospeche

Que 1 dia manco pensat,

Si t'ha fet trenta promeses,

Ninguna te $n$ cumplirà. ${ }^{11}$

Així mateix, en la producció teatral de Palanca i Roca veiem diversos exemples d'un altre tòpic recurrent de la literatura misògina: el de la dona cotorra, que xarra pels colzes i malparla d'uns i d'altres. Concretament, en Toni Manena y Chuan de la Son (1872), Chaume diu a la seua filla: «lo qu'és

9 Tres roses en un pomell (comedia bilingüe en tres actes, de costums labriegues), València, Impremta de Victorino Leon, 1870, pp. $12-13$

10 Op. cit., p. 29

11 Op. cit, p. 20

SCRIPTA, Revista internacional de literatura i cultura medieval i moderna, núm. 16 / desembre 2020 / pp. 383-399 
en llengua o palustre / li has eixit tota a ta mare» ${ }^{12}$ o en el miracle vicentí El rey moro de Granada, escrit conjuntament amb Bernat i Baloví i estrenat en 1960, el personatge de Pipare respon: «no sigues tan mentecato / que això són cuentos de dona». ${ }^{13}$

En aquests textos descobrim també el tracte denigrant cap a les dones a través de la burla i el menysteniment d'algunes circumstàncies derivades de la condició femenina. Un exemple el tenim en La millor raó, el trabuc, amb la següent sentència de Fumarell:

FUMARELL No sé lo que pot haver, mes yo crec, y no m'engañe, qu això és algun patatús d'eixos que tenen les dones. Conque no hi ha que fer cas y anem, alcalde, a lo nostre. ${ }^{14}$

Sense oblidar la cosificació de la dona per mitjà de comparacions amb elements que tenen una càrrega i un contingut clarament sexuals, com la que trobem en l'afirmació del protagonista masculí al final d'Un niu d'enredros (1873):

BATISTE Salero, viva la plata!

Tinc que dir-los a vostés que, dins d'un mes o poc més, m'embarque en esta fragata; foc li faré a tot pirata que vinga tirant sarpaes, que pa soltar canonaes tenim els dos pit y gran. ${ }^{15}$

A més, la sàtira misògina es desprén directament o indirecta d'alguns dels títols de les obres de Palanca i Roca, com els ja esmentats Llàgrimes d'una femella i Dos secrets en dos femelles. Però on es reconeix de manera més evident aquesta plasenteria és en el títol de la peça La gata moixa, atés que remet al caràcter malèvol d'una de les protagonistes darrere del seu posat de dona dòcil i servicial, d'ací que reba l'apel latiu misogin del títol.

D'altra banda, tots aquests tòpics van lligats indestriablement al masclisme que predomina en aquestes obres de teatre, reflex, una vegada més, de la societat d'aquells anys. Aquest masclisme es percep en les situacions quotidianes, com l'obediència cega de la germana al germà que reconeixem

12 Toni Manena y Chuan de la Son (choguet bilingüe, orichinal y en vers), València, Impremta de Ramon Ortega, 1872 , p. 12.

13

El rey moro de

Granada (Miracle), València, Impremta de D. Ignasi Boix, 1860, p. 6.

14 Op. cit., p. 23

15 Un niu d'enredros (choguet bilingüe de costums valensianes en un acte y en vers), València, Joan Mariana i Sanz, 1874, p. 30. 
en el següent fragment de Decrets de la Providènsia, estrenada en 1878, on Daniel expressa a la seua germana Dolores:

$\begin{array}{ll}\text { DANIEL } & \text { No és estrañ, pues, atingut } \\ \text { a lo que tu molt bé saps, } \\ \text { a que soc home y que conte, } \\ \text { aunque poca, més edat } \\ \text { que la tehua, que te diga } \\ \text { lo que deus fer y faràs. } \\ \text { Yo procuraré obedir-te. }{ }^{16}\end{array}$

El masclisme també s'observa en l'execució de les tasques domèstiques que sempre recau en les dones, com notem en l'obra Els dos anells, de 1874, en què Petra, seguint les instruccions del seu pare, Pascual, és l'encarregada de disposar l'habitació de Ricardo, convidat a casa, i de preparar després el sopar:

\begin{tabular}{|c|c|}
\hline PETRA & $\begin{array}{l}\text { Ya està } \\
\text { dispost, per a quant el vullga, } \\
\text { el cuarto del aloixat. } \\
\text { Lo celebro. }\end{array}$ \\
\hline $\begin{array}{l}\text { RICARDO } \\
\text { PASCUAL }\end{array}$ & $\begin{array}{l}\text { Lo celebro. } \\
\qquad \text { Si et pareix, } \\
\text { ves disponent el sopar. }\end{array}$ \\
\hline PETRA & Sí siñor. \\
\hline PASCUAL & $Y$ en ell fes conte \\
\hline $\begin{array}{l}\text { PETRA } \\
\text { PASCUAL }\end{array}$ & De qui més? \\
\hline
\end{tabular}

$\mathrm{Al}$ cap i a la fi, la pervivència d'aquests tòpics misògins heretats de la tradició literària, tant culta com popular, no és més que el resultat de la permanència d'un model de societat en el qual les dones estan sotmeses al jou opressor dels homes $i$, a més a més, i com a conseqüència d'aquesta situació d'inferioritat, són objecte de burla i mofa per la seua condició de dona. Tanmateix, en la producció de Palanca i Roca trobarem moments de reivindicació feminista que seran la rèplica a l'atac i l'escarni misogin.

\section{Francesc Palanca i Roca i la defensa de la condició femenina}

El tarannà liberal i la ideologia republicana de Palanca i Roca, units al seu origen humil, foren factors que el van conduir a involucrar-se políticament i cultural en el context valencià i a adoptar un comportament cívic envers els més necessitats i en favor de la justícia social. Fruit d'aquesta actitud d’implicació social fou el seu compromís amb l'educació i la seua preocupació per la situació

16 Decrets de la Providènsia (Drama en tres actes y en vers), València, Impremta de Joan Guix, 1878, p. 8.

17 Els dos anells (Drama bilingüe en dos actes y en vers), València, Joan Mariana i Sanz, editor, 1874, p. 16.

SCRIPTA, Revista internacional de literatura i cultura medieval i moderna, núm. 16 / desembre 2020 / pp. 383-399 ISSN: 2340-4841 · doi:10.7203/SCRIPTA.16.19236 
de les escoles d'aquell moment, inquietud que es veu reflectida en la seua obra Las escuelas en España, de 1874 , on critica i denuncia l'abandonament que patia la instrucció pública primària. A més, va col laborar estretament amb institucions de caràcter educatiu, cultural o benèfic com el Casino Obrer, l'Escola d'Artesans, l'Ateneu Científic i Literari, la Casa de la Beneficiència o l'Asil de les Germanetes dels Ancians Desemparats (Llobat 1996).

En aquesta línia és comprensible que la problemàtica social siga un tema recurrent en la seua producció, de manera que és fàcil trobar-hi diatribes contra els opressors i els tirans, l'opulència o les injustícies, i discursos encesos a favor de les classes humils, dels treballadors o de les causes lícites i legítimes. Per tant, com a resultat d'aquest esperit compromés, alguns personatges femenins de Palanca i Roca, sobretot les joves protagonistes, es reivindiquen com a dones i defensen la seua condició davant de les actituds i els atacs dels homes que les envolten.

Així mateix, convé no oblidar que les dones eren part integrant del públic que assistia a les representacions teatrals. Això significa que la presència en les obres de personatges femenins, que de tant en tant pronunciaren parlaments reivindicatius dels seus valors i la seua condició com a reacció a les burles, les ridiculitzacions i els atacs dels personatges masculins, era un atractiu més de la trama i, sembla lògic, que l'autor ho utilitzara com a recurs per a aconseguir l'afecte del públic femení.

D'aquesta manera, la reivindicació de la condició femenina davant de la crítica misògina també enllaça amb la tradició dels textos en defensa de les dones i, en particular, amb la tradició valenciana del segle XV. Comptat i debatut, l'aparició de l'Espill de Jaume Roig, el gran referent de la nostra literatura misògina, tingué la seua hipotètica rèplica en un altre gran exponent de la nostra literatura, en aquest cas, filògina, com és la Vita Christi de Sor Isabel de Villena, sense oblidar el Triümfo de les dones de Joan Roís de Corella. En el procés d'escriptura d'aquestes dues últimes obres, Isabel de Villena i Roís de Corella també pensaven potser en el públic femení. Però probablement també tenien en ment la provocació que va suposar el llibre de Jaume Roig, amb la qual cosa el debat al voltant de la condició femenina estava servit a casa nostra amb productes de la millor qualitat (Cantavella 1992a i 1992b).

Tanmateix, a diferència d'aquests textos filògins de la nostra tradició literària, que per a la defensa de les dones utilitzen les fonts bíbliques i teològiques i prenen com a model de virtuts la Mare de Déu, en les obres de Palanca i Roca són les mateixes dones que, amb un discurs valent, es reivindiquen davant de l'actitud dominadora i els comentaris misògins dels personatges femenins. I ho fan de maneres ben diferents. En primer lloc, des d'una perspectiva aparentment frívola, però ferma i seriosa per a reclamar la llibertat de decisió a l'hora d'elegir marit. Així, el personatge de Casilda, la jove viuda protagonista de l'obra Toni Manena $i$ Chuan de la son, amb gràcia i sense un pèl de vergonya, defensa, davant del seu pare, Chaume, la seua condició de dona i la seua llibertat per a triar, ja que el seu pare abans la va obligar a casar-se amb un home major que ella:

CHAUME No, com tu envides o truques, tenint flor, pedran els atres

SCRIPTA, Revista internacional de literatura i cultura medieval i moderna, núm. 16 / desembre 2020 / pp. 383-399 ISSN: 2340-4841 · doi:10.7203/SCRIPTA.16.19236 
CASILDA Però siñor, si bé 's mira, quins delits ni quines faltes són les qu estic cometent pa vindre'm sempre en cantaes? Total de tot, què ve a ser? Ö̈xquen, que van a asustar-se: vinguí al món molt chicoteta, (asò hu dic als que no hu sàpien), y els meus ulls ya eren luseros, segons contaba ma mare; aní creixent y me dien tots cuant de prop me miraben, en tindre tres sincs y un as, va a donar vergoña al ànchels.

CHAUME Chica, chica

CASILDA No s'asuste, que la mostra està palpable.

CHAUME Oy! Com palpable, guilopa?

CASILDA M'equivoquí, no s'espante. Diga palpable o visible, y és igual

CHAUME Tampoc m'agraes, qu entre palpable o visible... Oy! No dic res

CASILDA Pare, calle.

Seguí creixent y als catorse ya me cantaben albaes, y hasta el balcó me reblien de flors y frutes

CHAUME Tu acabes? (Impasientant-se)

CASILDA Per si en este em ria, colps; si era en aquell, navaixaes; y sinse tindre yo culpa de que tots foren uns cafres, per les preses de vosté fon presís, antes con antes, carregar en un marit als dèsat añs. Sort qu al atre li agarrà un còlic tancat y pipà. Déu que li hu pague. Sense fills, viuda y en cuens, pues sap que ne tinc en grande, templà, fina chove y guapa y alegre com unes pascues...

CHAUME Chica!

CASILDA Lo qu és natural!

Tornen tots a les anaes, y este em requiebra, aquell parla, patechen uns, rabien atres... 


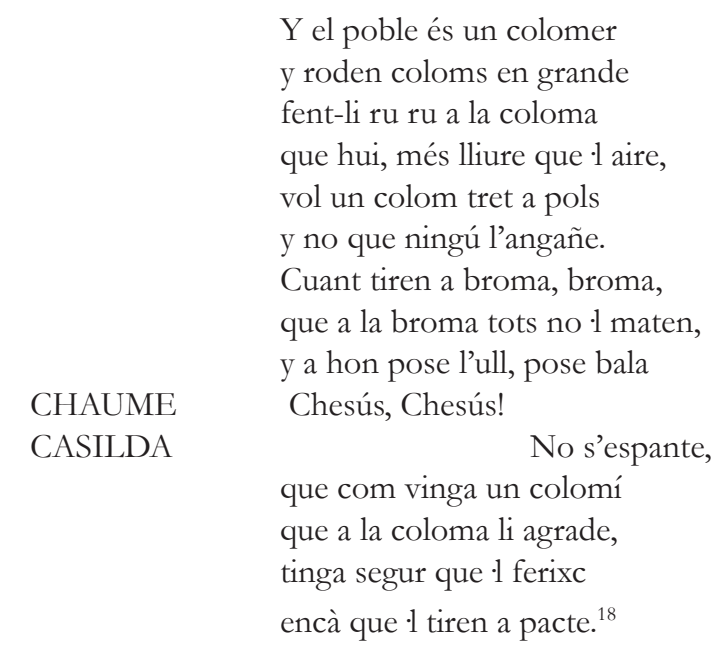

En segon lloc advertim la reivindicació de la dona des de la mateixa perspectiva de la sàtira misògina, és a dir, per mitjà de burla i mofa, en aquest cas, per part dels personatges femenins als homes i la condició masculina. Fet i fet, és el que Pepeta, la protagonista de Tres roses en un Pomell, porta a efecte, quan Batiste profereix un atac denigrant cap a les dones. A la frase provocadora de Batiste, «la dona és una gallina», Pepeta replica:

PEPETA Batiste! Y l'home és un gall! Pollastres en espolons que tot ho prenen a broma. Mes ya que parlem de ploma, seguim les comparasions. Gall és l'home, qu envanit de sa gran prepondrànsia, se pasecha en arrogànsia posant en lo sel el crit. El món se 1 troba chiquet y, per més que les polletes, y hasta les gallines fetes, li cacarechen propet, ell, més terne qu un titot, casi en despresi les mira, sols de cuant en cuant se chira pa moure algun alborot. $\mathrm{Y}$ entre veros y no veros, festa en festa y ball en ball, l'home és lo mateix que 1 gall: dos atajos d'embusteros. Inconstants, desagraïts, despòtics, desengañats,

18 Op. cit., pp. 12-13. 


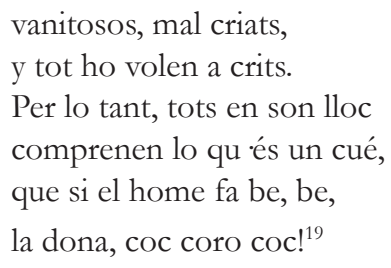

I finalment, al costat dels dos extrets anteriors, també trobem en altres personatges femenins un discurs altament reivindicatiu en favor de la dignitat de la dona $\mathrm{i}$ la igualtat entre homes i dones. Com per exemple, l'exigència d'Ànchela, la protagonista femenina d'Ortigues y roselles, de 1884, quan interpel la don Tomàs, un cacic despòtic que vol impedir que el seu fill es case amb ella:

ÀNCHELA

Aparte's!

Y no olvide, torpe o loco,

lo que así soc y el respecte

que $\mathrm{n}$ tot temps ha mereixcut

la dona. ${ }^{20}$

Però el gran parlament profeminista de la producció de Palanca i Roca el localitzem a l'obra Llàgrimes d'una femella, una peça de 1859, en la qual la protagonista femenina Maria articula un autèntic al legat en defensa de la condició femenina i de la igualtat, davant de les injustícies que les dones pateixen causades pels homes. Maria acudeix als sers divins i els pregunta el perquè d'aquesta desraó sobretot tenint en compte els temps que viu, en què ja es respiren els aires liberals que desembocaran en la Gloriosa. Aquest discurs encés, modern i valent resulta realment fresc per a l'època en què està escrit, tot i els elements marcadament sexistes que hi apareixen. Heus-ne ací la intervenció:

Copendre volguera yo
si, al traure-li la costella,
trovàreu, Siñor, en ella
gran diferènsia en la casta.
Digau-me si és d'atra pasta
que la que té esta femella!
Si fon vostra voluntad
que ell me respetara a mi,
digau, per què em trata així
En temps qu és de llibertad?
Com és que ell ha interpretat
paraula tan santa y bella
per a traure-li la estella
que ell a soletes s'engul
y no li n dona el gandul
chens a la pobra femella?

19 Op. cit., p. 13.

20 Ortigues y roselles (Comèdia dramàtica valensian en dos actes, orichinal y en vers), València, Impremta i Llibreria de Ramon Ortega, p. 46.

SCRIPTA, Revista internacional de literatura i cultura medieval i moderna, núm. 16 / desembre 2020 / pp. 383-399 


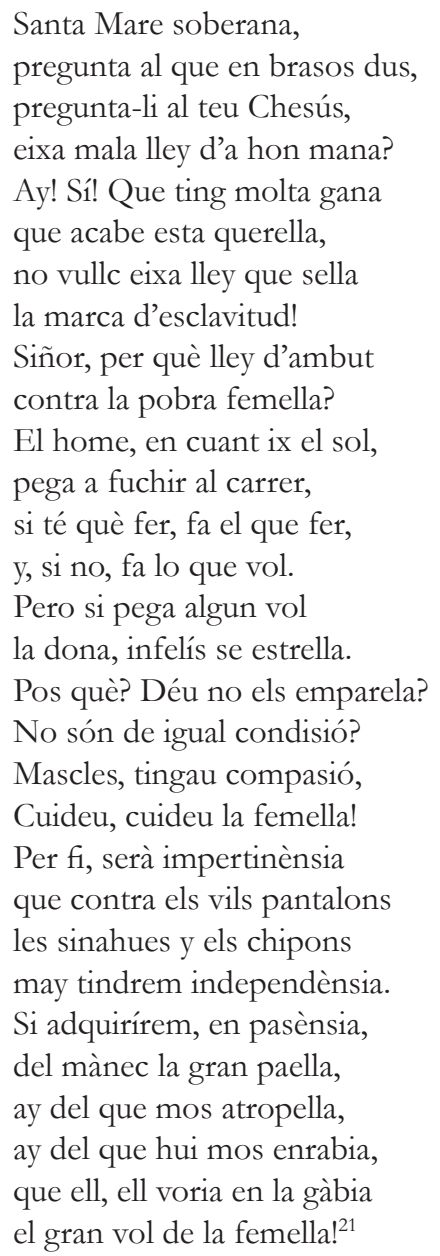

\section{Cloenda. Un debat que no es tanca}

Hem comprovat, doncs, com al llarg dels segles els tòpics misògins i la burla al voltant de la condició femenina s'han perpetuat en els textos literaris en paral lel a una societat androcèntrica $i$ patriarcal que arriba fins als nostres dies. O dit d'una altra manera: aquesta societat es reflecteix en la tradició literària en forma de plasenteria misògina, atacs satírics i crítiques jocoses, la qual cosa no és més que l'evidència de comportaments i actituds masclistes.

No obstant això, aquesta burla misògina tindrà una resposta en forma de defensa de la dona que també es pot resseguir en nombrosos exemples literaris de la nostra tradició. És cert que, com hem vist, els models per a la reivindicació de la dona són diferents al segle XV i al segle XIX. Al segle XV la Mare de Déu era la imatge de la dona virtuosa en la qual s'havien d'emmirallar les seues congèneres, mentre que a partir del segle XVIII, però sobretot del segle XIX, gràcies als nous aires

21 Op. cit., p. 19. 
liberals, és la dona mateixa, sense models religiosos, qui es reivindica davant de la tirania masculina, com hem pogut comprovar en alguns dels textos reproduits anteriorment.

Així, l'obra teatral de Francesc Palanca i Roca ens proveeix de nombrosos exemples d'aquesta disputa literària al voltant de la condició femenina. Les mostres que hem extret plasmen tant la sàtira misògina com la reivindicació de la dona i la igualtat entre els sexes. No cal dir que aquests conceptes relacionats amb el feminisme poden resultar anacrònics quan parlem del segle XIX. Tanmateix, la reivindicació de la dona està ben present en algunes obres de Palanca i Roca i, en aquest cas, a diferència del teatre d'Eduard Escalante, és possible que la visió de la realitat no estiga distorsionada o edulcorada i que, per tant, siga un reflex més o menys fidel del moment històric que es vivia.

A més, convé no perdre de vista que la plasenteria misògina literària, amb tot el contingut humorístic que es vulga, ha servit per a prolongar fins a l'actualitat una visió injusta, deformada i bisellada de la dona. En aquest sentit, les següents paraules d'Anna Maria Villalonga (2007: 81-82) reforcen aquesta idea:

\begin{abstract}
Al llarg dels segles, la situació indiscutiblement s'ha perpetuat, malgrat que, pel que fa a Occident, s’hagin produït avenços significatius en la dignificació del gènere femení. El Renaixement i el Barroc ofereixen tants exemples literaris contra les dones i contra el matrimoni, que es fa difícil (...) triar-ne un. El segle XVIII va representar un cert punt d'inflexió (...). Aquest tímid camí, que va obrir un debat que continuà de manera imparable durant el XIX i el XX, no ha suprimit ni de bon tros l'existència d'un pòsit antifemení inqüestionable, encara que més o menys amagat. Inserits com estem en una societat patriarcal, els sentiments negatius al voltant de la dona els trobem des de l'antiguitat a l'actualitat (sic). Estan presents en tots els àmbits de la vida i, com a conseqüència, a la literatura, culta i popular. De vegades, ficció i realitat es retroalimenten.
\end{abstract}

Tot plegat, les imatges misògines de caràcter burlesc i humorístic que s'arrepleguen en la producció dramàtica de Francesc Palanca i Roca continuen el fil de la tradició literària misògina, de la mateixa manera que les reaccions filògines que s'hi observen s'insereixen en la rèplica del debat sobre la condició femenina, amb referents diferents respecte dels de la literatura medieval, però en la mateixa línia de la controvèrsia. Així mateix, algunes de les reivindicacions en favor de les dones que s'adverteixen en certes obres d'aquest dramaturg poden ser llegides com a exigències valentes i atrevides per al moment en què estan escrites. És per això que en el marc del teatre popular del segle XIX, amb unes manifestacions escèniques que tendien normalment al tradicionalisme $i$, doncs, a la conservació d'un determinat model de societat i de relació entre els sexes, basat en la submissió de la dona cap a l'home, els discursos d'alguns dels personatges femenins de Palanca resulten sorprenents pel seu fons feminista avant la lettre. Aquest contingut de regust renovador i modern es troba en una part important de la producció teatral de l'escriptor d'Alzira, atés que el seu tarannà liberal i el seu republicanisme militant, com ja s'ha explicat més amunt, s'hi deixa notar a través de la defensa de les idees democràtiques, de les classes humils i dels grups discriminats i en contra de la tirania dels poderosos, de la corrupció i de les injustícies. 
Hilari Garcia Gázquez. L'herència del debat literari sobre la condició femenina en l'obra dramàtica de Francesc Palanca i Roca

\section{Bibliografia}

Baldó, M. (1995) «Els silencis d'Escalante. Nota sobre la València de fi de segle», Saó Monogräfics, 24, pp. 11-13.

. (1986a) «Els orígens del teatre valencià modern», dins El teatre al País Valencià durant la Guerra Civil (1936-1939), Barcelona, Curial, vol. 1, pp. 13-53.

- - (1986b) «Els valencians de la Restauració. Estudi sobre la composició de la societat valenciana del 1874 al 1902. I», Estudis romànics, XVIII, pp. 1-211.

Cantavella, R. (1992a) Els cards i el llir: una lectura de l'«Espill» de Jaume Roig, Barcelona, Quaderns Crema.

- (1992b) «Sobre El triunfo de les dones de Roís de Corella», Actas del II Congreso Internacional de la Asociación Hispánica de literatura Medieval, Alcalá de Henares, Universidad de Alcalá, pp. 217-228.

Carré, A. (2007) «Llegir l'Espill a la Baixa Edat Mitjana i avui», L'Avenç, 325, pp. 41-46.

Fàbregas, X. (1972) Aproximació a la història del teatre català modern, Barcelona, Curial.

—_. (1978) Història del teatre català, Barcelona, Millà.

—. (1979) Sainets del segle XIX, Barcelona, Edicions 62.

Garcia, H. (2015) «Els inicis de la sarsuela en valencià (1859-1874): Un casament en Picaña de Francesc Palanca i Roca i Joan Garcia Català», Studia Iberica et Americana, 2, pp. 810-842.

Gomis, J. (2008) «La sátira del matrimonio en pliegos sueltos y col loquis del siglo XVIII», Nuevo Mundo, Mundos Nuevos. Coloquios [En línia]. < https://journals.openedition.org/nuevomundo/26403> [darrera consulta: 30 d'octubre de 2020].

Metge, B. (1999) Lo somni, Barcelona, Quaderns Crema.

Mérida, R. (2000) «Mujeres y literatura de los medioevos ibéricos: voces, ecos y distorsiones», Estudis romànics, 22, pp. 155-176.

Llobat, F. J. (1996) Vida y obra de Francisco Palanca y Roca, Alzira, Falla Camí Nou-Ajuntament d'Alzira.

Sanchis Guarner, M. (1980) Els inicis del teatre valencià modern (1845 1874), València, Institut de Filologia Valenciana.

Sansano, Gabriel (1997) «Per una revisió del sainet valencià del segle XIX: Josep Bernat i Baldoví, un exemple», dins Josep Bernat i Baldoví, Teatre en valencià I (Obra Completa), Catarroja, Afers, pp. $13-22$.

- - (2014) «El teatre popular del segle XIX, dos exemples: Bernat i Baldoví i Eduard Escalante», Estudis filologics en homenatge al professor Joan J. Ponsoda, Alacant, Universitat d'Alacant, pp. 313-331.

Villalonga, A. M. (2007) «La literatura popular i la tradició misògina: algunes balades del Romancerillo catalán», Llengua \& Literatura, 18, pp. 75-106. 